$\mathrm{A} \int_{\cos } \mathrm{H}$

Article history :

Received : 21.04.2014

Accepted : 26.05.2015
THEASIAN JOURNAL OF HORTICULTURE

Volume 10 | Issue 1 | June, 2015 | 181-183

Visit us -www.researchjournal.co.in

\title{
Studies on quality evaluation of bael-aonla ready-to-serve (RTS) drink during storage
}

\section{OM SINGH, RICHA SINGH ${ }^{1}$ AND PRATIKSHA SINGH ${ }^{2}$}

Members of the Research Forum

Associated Authors:

${ }^{1}$ Krishi Vigyan Kendra, SITAPUR

(U.P.) INDIA

${ }^{2}$ Krishi Vigyan Kendra, CHURU

(RAJASTHAN) INDIA

Author for correspondence :

OM SINGH

College of Horticulture, Rajmata

Vijayaraje Scindia Krishi

Vishwavidyalaya, GWALIOR (M.P.)

INDIA

Email : Omsingh1921@gmail.com

ABSTRACT : The bael-aonla ready-to-serve (RTS) drinks were analyzed for chemical constituents at monthly interval for six months storage period during 2012-13. Total soluble solids and acidity increased, while ascorbic acid decreased in the beverages with the increase in storage duration. Overall acceptability of beverages increased by blending bael pulp with aonla pulp in comparison to bael or aonla pulp used alone for the preparation of beverages. In RTS drink, maximum acceptability (8.9) was achieved with 10 per cent pulp (50 bael : 50 aonla), 11 per cent TSS and 0.20 per cent acidity.

KEY WORDS : Bael, Aonla, Blends, RTS drink, Quality evaluation, Storage

HOW TO CITE THIS ARTICLE : Singh, Om, Singh, Richa and Singh, Pratiksha (2015). Studies on quality evaluation of bael-aonla ready-to-serve (RTS) drink during storage. Asian J. Hort., 10(1) : 181183. 